\title{
Private law theory and the past*
}

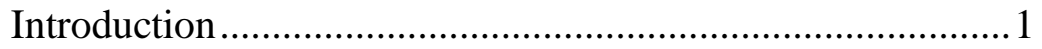

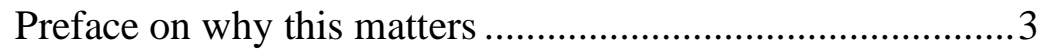

Private law theory .................................................................. 4

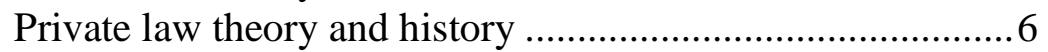

Precision, complexity and isolation ..................................... 9

Learning from philosophical history ..................................10

Philosophy and history....................................................... 11

Rational reconstruction ...................................................... 13

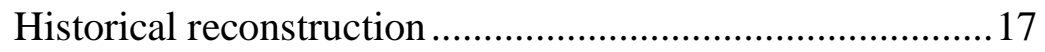

Geistesgeschichte ............................................................20

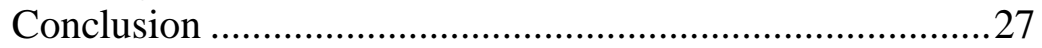

Private law theory plays a role (for better or worse) in the practice of law, whether that be in education or providing criticism, or contextualizing within a broader frame what private law does and why it does what it does. Yet some say that private law theory neglects history while others say that it does not fully capture history's possibilities. In this paper, I explore what it means to use history in theorising by exploring how analytical philosophy has engaged with history since the 1960s, suggesting three possible historical avenues of private law theory.

\section{Introduction}

Some say that private law theory neglects history while others say that it does not fully capture history's possibilities. ${ }^{1}$ Additionally, it has been said that the general approach of private

\footnotetext{
*Stephen Bogle, University of Glasgow, stephen.bogle@glasgow.ac.uk
}

Please do not cite without permission. At some point, I hope to publish this paper but for now, it is a working draft.

Previous iterations of this paper have been presented at the University of Edinburgh on 28 April 2017, the Loyola University New Orleans on 7 September 2017 and Tulane University on 9 September 2017. I am grateful to the participants for their comments, particularly Professor James Gordley and Professor John Lovatt. I am also grateful to Dr Triantafyllos Gouvas for his comments on a draft of this paper and also to Dr Chloë Kennedy for our continued discussions about the relationship between law, the past and history.

$1 \mathrm{~S}$ Waddams, "Classification of Private Law in Relation to Historical Evidence: Description, Prescription, and Conceptual Analysis" in Andrew Lewis and Michael Lobban (eds), Law and History, Current Legal Issues, vol 6, (2003) 265-284 at 267; B Bix, Contract Law: Rules, Theory and Context (2012) 151; M Hogg, Promises and Contract Law: Comparative Perspectives (2011) 173; S Hedley, "Corrective Justice - An Idea Whose Time Has Gone?" in M Del Mar \& M Lobban (eds), Law in Theory and History: New Essays on a Neglected Dialogue (2016) 305-325 at 308-309; W Lucy, The Philosophy of Private Law (2007) 425; H Dagan, Reconstructing American Legal Realism \& Rethinking Private Law Theory (2003) 23. 
law theory is too abstract without history. Specifically, these comments are directed towards contemporary Anglo-American literature of the last few decades. ${ }^{2}$ In this paper, I want to explore what it means to use history in theorising. ${ }^{3}$ What can history offer to theories about private law? How should history be approached? How can history and theory be done together? I will argue that history offers a legitimate and profitable path for theory. I do not contend that is it necessary but I do argue that it is potentially generative and instructive. I will try to show how history can be generative for theory by considering in very general terms how moral and political philosophy has engaged with history since the 1960s. Based on my brief survey of political and philosophical literature, I will suggest three types of historical approach which may offer new directions or genres for private law theory if (or when) it does engage with history. I also write this paper with a sense that there is a growing discussion across different forms or subsets of legal theory about the relationship between theory and history. There is a reassessment, in some fields of legal theory's relationship to and use of history or the past. Particularly in subjects like international law or criminal law there is an emerging historical consciousness, ${ }^{4}$ indeed it can also be seen in general legal theory. ${ }^{5}$ It is not so much that history has been forgotten and that

\footnotetext{
${ }^{2}$ In this paper, I'll confine my comments to Anglo-American literature. By this I mean work published in Anglo-American journals or printed by AngloAmerican publishers. I'd add that it is literature which is generally about case law rather than legislation or Codes; it is often focused on modes of legal reasoning and judicial adjudication and with an implicit common law focus. However, in European literature there are those who write and engage with Anglo-American private law theory thus the geographical nature of the distinction may be unsatisfactory. For example, Jans Smits, Ralf Michaels and Martijn Hesselink write in English, reference Anglo-American literature and appear to address similar questions. However, it is my impression that Smits, Michaels and Hesselink do not neglect of history in the same way as Anglo-American literature but that is for another day. See Franz Wieacker, A History of Private Law in Europe: With Particular Reference to Germany trans. by T Weir (1997); Ralf Michaels \& Nils Jansen, "Private Law and the State: Comparative Perceptions and Historic Observations" 71 Rabels Zeitschrift fuer auslaendisches und internationales Privatrecht (2006) 345397.

${ }^{3}$ I will use a basic distinction in this paper between the past, as in what has happened before now and histories, as in how we construct, order, understand and engage with the past.

${ }^{4}$ For international law, see M Craven, "Theorizing the Turn to History in International Law" in A Orford \& F Hoffman (ed), The Oxford Handbook of the Theory of International Law (2016) 22-38 and for criminal law see, N Lacy, In Search of Criminal Responsibility: Ideas, Interests, and Institutions (2016), Ch 6; L Farmer, Making the Modern Criminal Law: Criminalization and Civil Order (2016) Ch 10; and C Kennedy, "In Search of Criminal Responsibility: Ideas, Interests, and Institutions" EdinLR 21 (1) (2007) 133134.

5 See D Priel \& C L Barzun, “Jurisprudence and (Its) History” Osgoode Legal Studies Research Paper Series 11 (5) (2015); Special Issue, Opportunities for Law's Intellectual History, Buffalo Law Review 64 (1) (2016); M Del Mar \&
} 
the literature is rediscovering history but rather the role of history or the past is being reappraised. Therefore, if private law theory follows these developments what shape would it take?

\section{Preface on why this matters}

At the outset, it is worth expressing that our approach or understanding of private law matters, including how history is used by private law theory. Private law theory plays a role (for better or worse) in the practice of law, whether that be in education or providing criticism or contextualising within a broader frame what private law does and why it does what it does. Therefore, before suggesting the merits of a historical angle on such questions, which is essentially a theoretical or methodological exercise, it may be necessary to iterate why we should bother with private law theory in the first place.

First, we could be wasting our time in private law theory. Or possibly propping up an ailing unjust institution or idea. ${ }^{6}$ It might be that contract or property is something created by academics, which doesn't map upon either the practice of courts or commercial reality.

Second, organisation and definition matters in private law theory and this has consequences for individuals. ${ }^{7}$ Denying something is a contract with associated rights, may deny a remedy. Or saying something is a contract incorporating rights, may give a remedy. ${ }^{8}$

Third, private law enables as well as disables types of action. It creates and denies a space for action. Contracts transfer wealth and assets - they take from one person, and give to another. Tort provides remedies for wrongs, and if you are unsuccessful you may receive no compensation and no sense of justice. Property law protects your possessions, it excludes others from using, enjoying or benefiting from your material objects or creations. But if we decide that a creation such as song, invention or idea should not be defined as property it may mean that others can use or exploit what would otherwise be considered yours. Private law permits as much as it prohibits. ${ }^{9}$

M Lobban (eds), Law in Theory and History: New Essays on a Neglected Dialogue (2016); M Del Mar, 'Philosophical Analysis and Historical Inquiry: Theorising Normativity, Law and Legal Thought', in Markus Dubber and Christopher Tomlins (eds), Oxford Handbook of Legal Historical Research (forthcoming); and Markus D. Dubber has posted Legal History As Legal Scholarship: Doctrinalism, Interdisciplinarity, and Critical Analysis of Law in Dubber \& Tomlins (eds) Oxford Handbook of Historical Legal Research (forthcoming).

${ }^{6}$ N MacCormick, Practical Reason in Law and Morality (2008), Ch 8.

${ }^{7} \mathrm{H}$ Dagan, Reconstructing American Legal Realism \& Rethinking Private Law Theory (2013), Ch 5.

8 W Hohfeld, "Fundamental Legal Conceptions as Applied in Judicial Reasoning" (1917) 26 Yale Law Journal 710-770.

9 A Kronman, "Contract Law and Distributive Justice" (1979-1990) 89 Yale Law Journal 472; D Kennedy, "The Stakes of Law, or Hale and Foucault!" (1991) 15 Legal Studies Forum 328-361; and J Kraus, "Philosophy of 
Fourthly, there is the question of justification or political desirability. Some might say, if we cannot find suitable or satisfactory answer to these questions of both organisation and justification, we might then question whether modern private law is worth keeping or is in need to fundamental change. Even if we decide to keep such ideas, questions of welfare and efficiency may be asked. Is private law, as presently practiced, the best way to meet the goals or values it captures?

Fifthly, modern problems of global inequality or national inequality are indirectly linked to the private law structures that underpin and conceptualise our wealth, assets and rights as encapsulated within the domain of modern sovereign states. ${ }^{10}$

Sixthly, politicians, policy-makers and society at large may ask why we should retain the concepts of private law and not transition to less legalistic, esoteric and complex methods of managing property, contracts and wrongs. Private law theory addresses, albeit indirectly these larger questions but also these individual questions of remedy. If it isn't getting it right, then answering these questions become harder. Private law theory is about such things.

But what do I mean by private law theory?

\section{Private law theory}

Private law theory is a relatively new label, which could be more of a nuisance than assistance. Potentially, it is too early to say that there is something "new" here which requires a name. However, Peter Cane says "plausibly, the genesis of private law theory as a discrete area of academic study might be traced to the publication of Ronald Coase's famous article, "The Problem of Social Cost" in 1960"."11 In response, Cane says a rival school of analysis emerged in the early 1980s "loosely referred to ever since as "corrective justice theory.", 12 Another strand of thought, which could roughly be associated with private law theory is what Cane calls, "a critique of the ways in which (private) law affects the distribution of risk, wealth and power within society." 13 To a large extent, these remain the three schools of thought which dominate private law theorising. As John Goldberg has said existing "academic debates in private law theory over the last forty years have tended overwhelmingly to focus on, or presume the existence of, a fundamental divide between welfarist or efficiency theories, on the one hand, and

Contract Law" in J L Coleman, K Himma \& S Shapiro (eds), The Oxford Handbook of Jurisprudence and Philosophy of Law" (2004; 2012 online).

${ }^{10}$ M Blake, "Distributive Justice, State, Coercion, and Autonomy" (2002) 30 (3) 30 Philosophy \& Public Affairs 257-296; T Nagel, "The Problem of Global Justice" (2005) 33 (2) Philosophy \& Public Affairs 113-147; and A J Juilis, "Nagel's Atlas" (2006) 34 (2) Philosophy \& Public Affairs 176-192.

${ }^{11}$ P Cane, "The Anatomy of Private Law Theory: A 25 ${ }^{\text {th }}$ Anniversary Essay" OJLS 25 (2) (2005) 203-217, 203.

12 Ibid, 204.

13 Ibid, 205. 
deontological or rights-based theories, on the other. Indeed, anyone who writes in the private law fields is sooner or later asked to declare loyalty to one or another of these camps." 14

Not necessarily in contradiction with Cane's analysis, Steve Hedley has spoken about "Big Private Law Theory" as consisting of generally three approaches, the legal economists who see private law capturing "peoples' rights and entitlements in the market place, it defines what they can buy and sell, sets out the implications of each, and protects their choices to trade or not to trade"; the legal moralist who think private law makes "as a statement of personal responsibilities, and is in that sense rather more than a mass of technical rules"; and lastly, the doctrinalist, who "gives a clear exposition of what private law is - sums it up in a few key propositions or taxonomic structures and tries to leave it at that." 15 In a similar manner to Hedley, Nicholas McBride has written about three explanations of private law, i.e. the law and economics approach, the Kantian approach and legal moralism which could be taken to constitute "currently popular" ways to theorise about private law (particularly Anglo-American private law). ${ }^{16}$ When McBride speaks of "legal moralism" as a theory which takes tort law and private law more generally as "a form of applied morality..."17

The literature above suggests five different approaches within private law theory: law and economics, corrective justice, legal moralism, doctrinalist and critical legal studies. However, Cane captures a more streamlined presentation of private law theory, and if we follow his gloss that "justice theorists seem united in the idea that private law is best understood "noninstrumentally', as a relatively autonomous universe of normative discourse..." 18 then I think we could accommodate legal moralism and doctrinalists into a general category of theorist who see private law as, in Hedley's words, "more than mass of technical rules" but concerned with individual rights or obligations or duties which have an individual moral significance. Hence, I will use the term non-instrumental to describe the legal moralist, the corrective justice theorist and the doctrinalist. It could be challenged that the doctrinalist does not take a standpoint, at least if we follow Hedley's general description. I would argue the decision to take a neutral standpoint on the bigger questions of private law or to take an agnostic position nevertheless carries with it at the very least a latent positivism or potentially an implicit rejection of a law and

\footnotetext{
14 J C P Goldberg, "Introduction: Pragmatism and Private Law" (2012) 125 (18) HarvLRev 1640-1663, 1662.

15 S Hedley, "Is Private Law Meaningless" (2011) 64 (1) Current Legal Problems 89-116 at 90

${ }^{16}$ N McBride, "The Humanity of Private Law - An Introduction" University of Cambridge Legal Studies Research Paper Series Paper No 63 (2015) 1-49.

${ }^{17}$ Ibid, 30.

${ }^{18}$ Cane, 205.
} 
economics analysis and the critical studies position. That is, a doctrinalist rejects the notions that private law is accessory or ancillary to something else. In doing that, at the very least there is sense that one is committed to a non-instrumentalist perspective - they assuming there is such a thing as private law, that it can be ordered and organised without recourse to something other than the legal matter of courts, legislation and other legal material. Therefore, if this division is workable, we are left with the instrumentalists, the non-instrumentalists and the critical studies approach to private law.

\section{Private law theory and history}

It might first be useful to examine in more detail what private law theory is said to neglect. Some argue that private law theory is imprecise. Others say it ignores the complexity of law and its historical development whereas some are concerned with whether the history of law offers anything generative for theory. In terms of instrumentalist and non-instrumentalists, complaints are often concerned with the lack of either geographical or temporal precision. For example, Stephen Waddams has said that in "assessing the many and various accounts that have been offered of Anglo-American private law, it is often difficult to tell to what extent the statements about law includes or implies actual assertions about the past." ${ }^{19}$ More directly, Brian Bix has said that "contract theory should focus on a single legal system at a particular time; thus, there should usually be different theories of different countries (although each different country's theory would be dependent on how divergent the rules and practices are)." ${ }^{20}$ In a similar vein, Martin Hogg has argued that theories of contract law should be explained according to time, place and circumstance rather than holding to the vague notion of discovering the Platonic truth or pure essence of "contract law". To Hogg, "Searching... for a single and universally correct theory of contract, one that will hold good at all times and in all places, seems flawed." 21 Speaking specifically about corrective justice scholars, Steve Hedley has criticised the "reluctance [of corrective justice theorists] to commit themselves to a particular place and time (and so assuming that 'private law' has an essence which transcends particular legal jurisdictions)." 22

Others are more concerned with the complexity of law and how the past relates to contemporary theories. For example,

$19 \mathrm{~S}$ Waddams, "Classification of Private Law in Relation to Historical Evidence: Description, Prescription, and Conceptual Analysis" in Andrew Lewis and Michael Lobban (eds), Law and History, Current Legal Issues, vol 6, (2003) 265-284 at 267.

${ }^{20}$ B Bix, Contract Law: Rules, Theory and Context (2012) 151

${ }^{21}$ M Hogg, Promises and Contract Law: Comparative Perspectives (2011) 173.

${ }^{22}$ S Hedley, "Corrective Justice - An Idea Whose Time Has Gone?" in M Del Mar \& M Lobban (eds), Law in Theory and History: New Essays on a Neglected Dialogue (2016) 305-325 at 308-309. 
William Lucy has challenged the assumption found in private law theory "that some or all of the principal and structural features of private law will prove to be both intelligible and normatively respectable." 23 For Lucy, "the assumption seems particularly dubious when private law's history and complexity in the common law is borne in mind: it is the work of many many minds over a long period of time and has developed without the guidance that might be provided by a pre-existing blueprint." 24 Or as Hanoch Dagan has said, "the heterogeneity of contemporary understandings of any given legal concept (such as property or contract) within and outside any given jurisdiction, as well as the wealth of additional alternatives that legal history offers, defies the formalist quest for conceptual essentialism." ${ }^{25}$ Sheehan and Arvind have said that private law theory is dominated by conceptual debates but that "taxonomy...cannot be done through definition or deterministic logical reasoning, but turns equally on questions of purpose...context... and history..." ${ }^{26}$ Moreover, Anat Rosenburg has argued that the field of contract theory as well as legal history has settled on a simplistic understanding of contract's history. She notes a strange contradiction in that "no historian would resist the suggestion of cultural complexity, of contradictory or alternative interpretations of contract and of individualism in contract, certainly not after the cultural turn of the last few decades. Contract histories, however, have not only left this issue little explored and little conceptualized; they have somewhat inadvertently secured the opposite notion of cultural homogeneity." 27 By implication, Rosenburg suggests that both legal history and contract theory allow each to misuse, misinterpret or ignore each other's conclusions in order to support their own narratives or explanations.

Critical Legal Studies, by contrast, is rich with history but is losing its connection with theory or a sense of direction. ${ }^{28}$ Hence, you do not find express statements in the literature lamenting neglect or ignorance. Indeed, one of the lasting impacts of the critical studies movement has been critical legal history, which in many instances is somewhat indistinguishable from general history in its method. ${ }^{29}$ History has been important to the approach of Critical Legal Studies; in a similar way to

\footnotetext{
${ }^{23}$ W Lucy, The Philosophy of Private Law (2007) 425.

${ }^{24}$ Ibid.

25 H Dagan, Reconstructing American Legal Realism \& Rethinking Private Law Theory (2003) 23.

${ }^{26}$ D Sheehan \& TT Arvind, "Private law theory and taxonomy: reframing the debate" (2015) 35(3) Legal Studies 408-501, 501.

${ }^{27}$ A Rosenburg, "Contract's Meaning and the Histories of Classical Contract Law" 59 McGill Law Journal 165, 1-43, 37.

${ }^{28} \mathrm{R}$ W Gordon, Taming the Past: Essays on Law in History and History in law (2017).

29 See Symposium on Gordon's “Critical Legal Histories" Law \& Social Inquiry (2012) 147-215.
} 
empirical studies which demonstrate contradiction or the dissonance between rhetoric and practice, or studies which outline the indeterminacy of legal reasoning, historical approaches often demonstrate the contingency or fluidity of law. Or critical studies might stress, through historical methods, that law is a product of social factors, interests or politics. Historical approaches can show how society, power and policy have produced or shaped or influenced and continue to form what private law is in both a direct and indirect manner. Therefore, it might appear strange to say that critical legal theory should pay more attention to history and what it can offer. But some have questioned how history is used in critical historical studies.

Katharina Isabel Schmidt, for instance, has said that "what they have not always done [critical legal historians]... is draw on large historical time scales for the purpose of formulating, illustrating, and strengthening their arguments." 30 She went on to say, theorists of private law and legal historians generally should not, however, "shy away from big ideas and big legal history..." ${ }^{31}$ Speaking specifically about the limitations of critical legal history and its general message, Robert Gordon has acknowledged that "the notion that every form of legality is a constructed artifact rather than a natural or determined fact is useful for understanding the genealogy of current conditions, but at the same time tends ... to deprive people of any strong basis for confidence in transcendent standpoints for critique of the present order." 32 Chris Tomlins is concerned as to where this contingency leads. He says "ultimately, totalized contingency is a deeply tragic form of subversion, for it does not discriminate in the paralysis it metes out. In undermining the authority of all narratives, it spares none, not even those that may be precious to the powerless, those whom we once desired to liberate." ${ }^{33}$ When he asks what is left of the critique once contextualisation and contingency are accepted, he concludes that "the final and unfortunately depressing answer to our question may be that what is left after critique is merely a blur of similitude, as the field of law and society joins all post-critical scholarship in the energetic but sadly pointless pursuit of an essentially bourgeois aesthetic of complexity, of endless, causeless relationality." ${ }^{34}$ To

\footnotetext{
${ }^{30}$ K I Schmidt, "Henry Maine's 'Modern Law" "From Status to Contract and Back Again” (2017) 65 The American Journal of Comparative Law 145-186, 185-186.

${ }^{31} \mathrm{~K}$ Isabel Schmidt has made this sort of argument: K I Schmidt, "Henry Maine's 'Modern Law" "From Status to Contract and Back Again" (2017) 65 The American Journal of Comparative Law 145-186, 185-186.

${ }^{32}$ R W Gordon, "The Past as Authority and as Social Critic: Stabilizing and Destabilizing Functions of History in Legal Argument" in T J McDonald, In The Historic Turn in the Human Sciences (1996) 339-378, 365.

${ }^{33} \mathrm{C}$ Tomlins, "What is left of the law and society paradigm after critique? Revisiting Robert Gordon's 'Critical Legal Histories"'37 (1) Law and Social Inquiry (2012), 155-166, 166.

34 Ibid.
} 
be sure, Gordon is not as concerned as Tomlins: he says "all history can tell us is that opportunities for remaking law always exist and, if seized in the sport of adventure and pragmatic experiment, may sometimes lead to better state of the world than those we have come to accept out of compliancy or despair." 35 For as much as this has consequence for general understandings of law, it has relevance to how critical legal scholars theorise about private law.

\section{Precision, complexity and isolation}

These complaints or concerns which are found in literature relating to private law theory divide into three types of complaint concerning: precision, complexity or isolation. But each, I would say, equally supposes there is a role for history but does not make that role evident or use it in a generative or productive way. ${ }^{36}$ First, it appears that what some scholars like Hogg or Waddams want is more specificity, which may not equate to a request for more history but would is suggestive of its ability to provide it. Arguably, however, what is at the heart of these types of complaint is that private law theory be bolder: either a theory state that their approach transcends, applying across the history of law or it does not. A theorist may just say, 'yes, my theory does apply universally' but it was either forgotten, misunderstood or not discovered until now. However, there is an underlying suspicion or strategy in these complaints: that many private law theorists do not want to make the universal claim but do wish nonetheless to benefit from the explanatory reach of a universal claim. However, by posing the specificity-question or complaint towards private law theory you are at the first step in an argument, which eventually works towards a relativity claim about private law. Second, those like Dagan and Lucy, who stress the complexity of law and its past, are posing a challenge, suggesting the burden of proof is upon the theorist. ${ }^{37}$ That is, in making the universal claim it could be argued that a theorist should be prepared to support this theory with a version of history which generally supports their claims. ${ }^{38}$ Often the concern is that private law theory has reduced and flatten the

\footnotetext{
${ }^{35}$ R Gordon, “CCritical Legal Histories Revisited': A Response” (2012) 37 (1) Law \& Social Inquiry 200-215, 215.

${ }^{36}$ Tomlins has offered an extensive theory as to what role history can play: C Tomlins, "The Strait Gate: The Past, History, and Legal Scholarship (2009) 4 Law, Culture and the Humanities 11-42; “After Critical Legal History: Scope, Scale, Structure (2012) 8 Annual Review of Law and Social Science 31-68. I would link his theory to the imaginative role which rational reconstruction can offer, which is discussed below.

${ }^{37}$ For a good example of this type of challenge, see J Goupkamp \& J Murphy, "The Failure of Universal Theories of Tort Law" (2015) 21 Legal Theory 4785.

${ }^{38}$ I'd suggest that the work of James Gordley is an important exception to this: J Gordley, The Philosophical Origins of Modern Contract Doctrine (1991); Foundations of Private Law (2006).
} 
contours and density of private law to banal statements or disconnected generalisations. Again, it may be that the strategy here is attempting to place the burden of proof upon the abstraction or equally a step towards adopting a more relativist conception of your theory of private law. ${ }^{39}$ Or it could be a genuine request to understand how and in what ways the general theory relates to law's past and its changing nature. Third, there is the concern posed by Tomlins and acknowledged by Gordon. If you continually contextualise, stress the contingency of law, speak of its fluidity, then you are left, potentially, without a positive or most substantive message or purpose. Such an opinion may take you towards the type of approach advocated by, for example, Schmidt. Indeed, Schmidt's confidence raises the question of where private law theory may go if it takes up the challenge of engaging with history and the past and what that type of scholarship would look like. Indeed more widely, if the problems of imprecision, reduction and isolation are to be addressed by taking private law's past seriously then it would be of benefit to consider how philosophy has engaged with the past.

\section{Learning from philosophical history}

It might be asked, why not learn from other disciplines such as economics, sociology or anthropology? Each has in its own way engaged with either the history of their discipline or what the past means in terms of method. It could be said that preferring philosophy needs some justification; but I hope not too much. First, a large branch of philosophy seeks to explain, understand or analyse normativity itself or structures, behaviour and practices which are normative. Second, conceptual analysis is a central task of contemporary philosophy and consideration of concepts use and deployment a common concern of political and moral philosophy. Understanding, examining and considering the use of concepts is a key part of private law theory there would appear to be a similarity in method to a great or lessor extent. ${ }^{40}$ Third, and related to the second is that to a large extend contemporary private law theory is a form of philosophy (broadly defined). Or you could say it borrows from philosophy arguments, modes of analysis and theories. Therefore, I do not see any meaningful difference between a philosophical enquiry

\footnotetext{
${ }^{39}$ For example, see A Beever, Forgotten Justice (2013) and its withering critique, D Priel, "Private Law: Commutative or Distributive?" Osgoode CLPE Research Paper No. 56/2013, published in the (2012) 77 (2) Modern Law 308-331.

${ }^{40}$ Conceptual analysis can be understood as (i) disassembling a concept into its competent, and revealing the logical relationship between each of those parts; or (ii) breaking down a concept to constitutive parts through a process of rolling back until you reach a fundamental level or first principles required to constitute the concept; or (iii) it can also be understood as a process of interpretation and transformation of a concept into logic or more basic concepts which represent a more fundamental description of what is being considered.
} 
into law or private law specifically and say a philosophical enquiry into knowledge, identity or causation or in fact economics, politics, morality or literature $;{ }^{41}$ adding law or legal merely specifics the field of study, i.e. law. The same goes for the term "history" or using the prefix of legal before history. There does not seem to be any major difference between history in general and legal history apart from the focus. ${ }^{42}$ But maybe it would be safer to bracket off definitional questions of what philosophy or what history is and what is the difference between legal philosophy and philosophy more generally. One reason to bracket things at this stage is because depending on your mode of enquiry, you may in fact be asking the very question, what legal philosophy is, or what legal history is, and using history or denying the usefulness of history in answering such questions. However, I would hope that we can accept that legal theory, legal philosophy and philosophy, as practiced today, share similarities and have a relationship of some sort. If there are meaningful differences, I would hope that they do not necessarily preclude my attempt to draw parallels between literatures about philosophical history in general and the present discussion about the potential for a dialogue between legal theory and legal history.

\section{Philosophy and history}

Richard Bernstein says in the 1960s there was "a smug conviction that the analytical styles of doing philosophy were the only legitimate ways of doing philosophy." 43 Such approaches to philosophy were "taken to represent standards of clarify, rigor, precision, and argumentative finesse" whereas there was a "denigration of the philosophic value of studying the history of philosophy and engaging with philosophic classics." 44 However as Richard Rorty noted the "more 'scientific' and 'rigorous' philosophy became, the less it had to do with the rest of culture and the more absurd its traditional pretensions seemed." ${ }^{45}$ In turn, attempts of analytical philosophies, according to Rorty to "ground" this or "criticize" were and are "shrugged off by those whose activities were purported being grounded or criticized." 46 Part of the problem, according to Alasdair MacIntyre, was (and

\footnotetext{
${ }^{41}$ I do not think - at least for the purposes of this paper - there is any significant difference between the terms legal theory and legal philosophy. I take both phrases to describe a form of legal scholarship which takes a philosophical or abstract or reflective approach to the study of law or legal institutions.

42 This may put me somewhat at odds with how David Ibbeston defines legal history, i.e. as solely focused upon legal doctrine and rules. However, historians might see law differently from internal legal historians and as an (ever present) part history, E P Thompson, The Poverty of Theory (1978) 103.

${ }^{43}$ R Bernstein, Praxis and Action (1979; reprint 1999) ix

${ }^{44}$ Ibid, ix

${ }^{45}$ Ibid, 5

46 Ibid, 5
} 
still is) that "what analytical philosophy gains in clarity and rigor, it loses in being unable to provide decisive answer to substantive philosophical questions." ${ }^{47}$ It can, according to MacIntyre, "rule out certain possibilities" but "for each alternative view that remains" it can only identify "what commitments one will be making by way of entailments and presuppositions, it is not capable in itself of producing any reason for asserting any one thing over any other."48 In 2002, Williams said much the same; "a lot of philosophy is more blankly non-historical now than it has ever been. In the so-called analytic tradition in particular this takes the form of trying to make philosophy sound like an extension of science."49 But for Bernard Williams what was problematic wasn't being neglectful of philosophy's own history but rather being neglectful of the history of its concepts. ${ }^{\mathbf{5 0}}$ David Plunkett has returned to this idea in recent years, arguing that the facts about a concept's history or genealogy can hold relevancy for normative inquiries. It can help us understand whether the replacement of one concept with another will ameliorate supposed difficulties or deficient but also illuminate what might be sacrificed through the replacement of one concept with another. Additionally, the "causal-explanatory reasons why agents started using a concept" may help understand any given concept's content; thereby revealing factual rather logical constraints upon the concept's development or use. ${ }^{51}$

In 1984, Rorty, Schneewind and Skinner published an edited collected, Philosophy in History: Essay in the Historiography of Philosophy. ${ }^{52}$ It collected together a series of lectures given by philosophers, such as Rorty, MacIntyre and Taylor, philosophers sympathetic to the study of philosophy's history and its possibilities. In a soft tone, the editors remarked that "in Britain and America, the historiography of philosophy has recently been less self-conscious than it ought to have been." 53 They noted, "the influence of analytic philosophy has worked against the self-consciousness of the sort desired." ${ }^{54}$ But more pointedly, they said analytical philosophers have "seen no need to situate themselves...because they take themselves to be

${ }^{47}$ G Borradori, The American Philosopher: Conversations With Quine, Davidson, Putnam, Nozick, Danto, Rorty, Cavell, MacIntyre, and Kuhn by Giovanna Borradori (1994) 145.

${ }^{48}$ Ibid, [...].

${ }^{49}$ R Rorty, J B Schneewind, Q Skinner (eds), Philosophy in History: Essays in the Historiography of Philosophy (1984).

${ }^{50}$ B Williams, "Why Philosophy Needs History: On Truth" LRB 17 October 2002.

${ }^{51}$ D Plunkett, "Conceptual history, conceptual ethics, and the aims of inquiry: a framework for thinking about the relevance of the history/genealogy of concepts to normative inquiry" (2016) 3 (2) Ergo 27-64.

${ }^{52}$ R Rorty, J B Schneewind, Q Skinner (eds), Philosophy in History: Essays in the Historiography of Philosophy (1984), preface.

${ }^{53}$ Ibid

${ }^{54}$ Ibid 
the first to have understood what philosophy is, what questions are genuinely philosophical ones." ${ }^{55}$ It was suggested by the editors that the lack of self-consciousness was less apparent before analytical philosophy because in days gone by philosophy was taught in a far more historical manner. However, this too had its drawbacks in that it produced "the excess of historical self-consciousness which Nietzsche characterised as 'a disadvantage of history for life." But the benefits of such an approach, per Rorty, Schneewind and Skinner were that it inculcated a "sense of historical contingency, a sense that philosophy has meant many quite different things." 56 Nevertheless, they were clear that they did not deny the analytical philosophy was of value nor did they think that philosophy was "best done in the form of a historical commentary." But they did stress the notion that analytical philosophers are "missing a desirable form of self-consciousness as long as they ignore attempts of intellectual historians to inculcate a sense of historical contingency." 57

If it be granted that there is something useful which can be taken from philosophy's own discussion of its methodology and approach to history, and particularly these three genres, then I think we can take guidance and direction in scoping out what kind of literature would emerge from a dialogue between legal theory and history. ${ }^{58}$ Understanding the different ways that philosophy has engaged with history helps map out the paths which private law theory (and legal theory more generally) might take. The three paths are rational reconstruction, historical reconstruction and geistesgeschichte histories. ${ }^{59}$

\section{Rational reconstruction}

Rational reconstruction is one path. Rorty's description suggests that this approach works on two levels. First, it involves articulating the argument, theory or idea of a historical writer. Second, it involves either affirmative or dissension from a

\footnotetext{
${ }^{55}$ Ibid

${ }^{56}$ Ibid

${ }^{57}$ Ibid

${ }^{58}$ In this paper, I will not cover the anti-metaphysical turn or the pragmatic turn since the 1960s. Although crucially important to how one understands contemporary moral and political philosophy, I think a direct focus upon this topic would warrant a separate paper. Additionally, I think the discussion of rational reconstruction to some extent captures a pragmatic approach but certainly does not give an exhaustive account. See J Rawls, "Justice as fairness: political not metaphysical" (1985) 14 (3) Philosophy and Public Affairs 223-251; R Rorty, "The priority of democracy to philosophy" in J P Reeder \& G Outka (eds.), Prospects for a Common Morality (1992) 254-278; and I Hunter, "Is metaphysics a threat to liberal democracy? On Richard Rorty's 'The Priority of Democracy to Philosophy' (2000) 95 Theoria: A Journal of Social and Political Theory 59-78.

59 I have taken these three genres from Richard Rorty's summary of approaches of philosophy's history. He also includes doxology which I won't consider here.
} 
historical text. At this first level, you may decide to lay out the premises and to make explicit, in logical form, the argument used to support the theory. Or you might decide, at this level of reconstruction, to make explicit a step in the argument which is missing. Additionally, you may wish to underline an inconsistency or contradiction. You might highlight a concept or idea which could improve or advance the argument. Alternatively, you might draw attention to something, a later development in science for example, which undermines the argument, theory or idea. You do all of this with the intention of making clear, making explicit, and defining the theory or idea in consideration. In this of rational reconstruction, you make the theory or idea adhere to a conception of rationality which allows you to engage with the text. At this first level, rational reconstruction involves the process or re-articulation, reformulation and rephrasing of a historical text. You update it and treat the author as a contemporary.

But why do this? What is the point? This leads to the second level. You might say that you read rationally reconstructed historical texts to inspire new ideas or to correct (influential) historical ideas. For example, you entertain the thoughts of a dead philosopher in the hope of seeing a hidden premise, an alternate answer, or to inspire a new development. Of course, Schopenhauer said "reading is merely a surrogate for thinking for yourself, it means letting someone else direct your thoughts. " ${ }^{60}$ But aphorisms aren't always right. Reading can also act as a muse. We can construct (or clarify? or reveal?) an idea from what we have read or arguably an idea may emerge from the process. When you pick up a book, say on legal philosophy you are challenged to consider someone else's ideas and during that process cross-reference those ideas with your own. Do I agree? Am I convinced? What have they possibly overlooked? What of my experience would undermine this theory? These are questions we are taught to ask of a text, at least those produced in an academic context. And through the process of reading and engaging with another's thoughts we are, if not thinking in monastic isolation, at least enlivening our mind with ideas.

However, a rational reconstructor is not randomly selecting historical texts to stimulate ideas like a surrealist artist loosening their imagination. Often, in academic disciplines our choice in historical texts is shaped by our field of study. We inherit or receive texts which have formed a new way of thinking or created a new paradigm. Textbooks, reading lists and prescribed syllabuses can determine what historical texts we may encounter. For example, Hugo Grotius's De Jure Belli au Pacis from 1625 established a new form of natural rights theory and is often quoted to this day. He can be a source of modern day ideas about international law or theories of rights. Rationally

${ }^{60}$ A Schopenhauer, Essays and Aphorisms (1970) [...]. 
reconstructing the argument of an influential writer can help loosen their influence, it can help a discipline realise the errors of a foundational text, or it can help a field of study advance beyond inherited theories and ideas which on reconstruction appear weak. Equally there can be a process of inspiration, where you see a missing premise or step which could be taken which might allow one to build upon a foundational text.

Of course, the complaint of anachronism looms large with rational reconstruction. But as Rorty argues, if rational reconstructions are "conducted in full knowledge of their anachronism, they are unobjectionable." ${ }^{61}$ Because the only real problem is verbal, and nothing much hangs on the question of whether a rational reconstructor is doing "history" or "philosophy" when he or she tries to clarify what was said by a historical writer. However, more serious problems emerge when someone claims to reveal or unveil what someone "really" meant when the author never said anything of the sort and it is difficult to take such a meaning from their work. Then the question of what someone is doing becomes more important because someone is making a descriptive claim about the past which is difficult to verify and at best speculative. However, there is nothing disagreeable about a rational reconstructor offering a premise to a historical writer - so long as they know and make clear that they are not claiming this premise to be buried in the past and unannounced until now.

Ian Hacking has referred to this method as the "penfriend approach" 62 and Rorty has described this as making the "dead our conversational partners." 63 It is the process by which a reader engages with the text of and from that he or she takes away an opinion, theory or germ of an idea. The reader can then develop from this either their own idea, adopt what they think is the idea of that author or they can correct and instruct the author. However, the reader may not be, strictly speaking, sensitive or fully attentive, sometimes deliberately so, to either the intention of or context within which the original author of wrote the text. But for a rational reconstructor, there is no problem. They are possibly looking for an interlocutor, which can involve correcting or updating the ideas of the historical writer or disagreeing with them. The historical text is therefore a sounding board or used for a point of contrast or used as placeholder for an opinion or idea which the reader attributes to the text or writer.

After you have rationally reconstructed a historical text, the benefits of such an approach might appear superficial. Reformulating an influential historical text does not ensure its overthrow. Dodgy theories, supported by bad arguments persist;

\footnotetext{
${ }^{61}$ R Rorty, "The Historiography of Philosophy: Four Genres” in R Rorty, J B Schneewind, Q Skinner (eds), Philosophy in History: Essays in the Historiography of Philosophy (1984).

62 I Hacking, "Five parables" 103

${ }^{63}$ R Rorty, "The Historiography of Philosophy: Four Genres" 247.
} 
belligerent interlocutors are all too common. You might say then that making contradiction or inconsistency clear does not always work. Going to the trouble of rational reconstruction is a waste of time. But as Rorty showed in his book, Philosophy and the Mirror of Nature using history and well-known figures in your analysis of philosophy gives flesh to the bones. As I said earlier, Rorty argued that "more 'scientific' and 'rigorous' philosophy" becomes "the less it has to relate to culture and world we experience. By taking to task, for example, and influential writer, through rational reconstruction, you can "ground" your criticism and make it more difficult for the listener to shrug it off. ${ }^{64}$ Rational reconstruction which is historical can also, as I said, inspire. Again, as I noted earlier, according to MacIntyre, part of the problem which analytical philosophy faces is that it is often "unable to provide decisive answer to substantive philosophical questions." 65 It can, according to MacIntyre, "rule out certain possibilities" but "for each alternative view that remains" it can only identify "what commitments one will be making by way of entailments and presuppositions, it is not capable in itself of producing any reason for asserting any one thing over any other." ${ }^{66}$ But as I have suggested, you can through the process of rational reconstruction spot an opportunity, an alternative or a possible development which is profitable.

You might say, what's the difference between reading a contemporary text and a historical text? Based on my description, rational reconstruction does not appear to be much more than a literature review, albeit a potentially far reaching one in terms of time. Furthermore, it carries with it the implication that you do not necessarily care for the historical meaning or intention of the author. On that basis, reading the Merchant of Venice is just as useful as reading Grotius - both offer a seventeenth century consideration of contracts. Neither of these are necessarily reasons to reject a rational reconstruction of a historical text. They could merely be descriptions of how one engages with a text which you disagree with. Moreover, at an elementary level, rational reconstruction may ensure you do not repeat some else's thoughts or enable you to distinguish yourself from a historical writer. Or you can show why your new concept or idea is an improvement or advancement. This is not a frivolous point.

For example, "the descriptive information that we get from doing conceptual history can help us make progress in figuring out which concepts will help make a given instance of

\footnotetext{
${ }^{64}$ Ibid, 5

${ }^{65}$ G Borradori, The American Philosopher: Conversations With Quine, Davidson, Putnam, Nozick, Danto, Rorty, Cavell, MacIntyre, and Kuhn by Giovanna Borradori (1994) 145.

${ }^{66}$ Ibid.
} 
inquiry go best." 67 It can give us counterexamples of why replacing a concept or idea is not an improvement or demonstrate similar moves which have been unsuccessful. As Plunkett says, "awareness of such historical facts can help one be attuned to aspects of a concept's content that one might otherwise overlook or failed to adequately appreciate" if it were not for the knowledge we have of how the concept emerged or developed in a specific period for a specific need ${ }^{68}$ Indeed, it can involve a more serious engagement with the author, which requires the theorist to clarify their own view point. A good example of this, I think, is Neil MacCormick's consideration of Kant, Smith and Viscount Stair in Practical Reason and Morality and Law. In that book, MacCormick reconsidered Smith's impartial spectator, Kant's categorical imperative and Stair's notion that law was the dictate of reason. He clarified in his own terms each idea and reinterpreted each author. From this MacCormick offered an account of property, contract and liberty based on a rational reconstruction of these authors. But for all its merits, the rational reconstruction path can only recommend history; it does not mean it is necessary or essential to provide an adequate theory of an institution or practice such as private law.

\section{Historical reconstruction}

Another path is historical reconstruction. Here you take the text and construct it in a manner which is sensitive to the context, convention and intention. The theory or idea is constructed, avoiding anachronism or the temptation to project into the past modern ideas. Utmost care is often given to the sources being handled and their authenticity. Dates, times and places are as important as a clear articulation of the theory. But the theory or idea will never be constructed in a manner which deviates from the original intention of the author. To use Skinner's maxim, "no agent should be said to have done or meant something which that agent could never be brought to accept as a correct description of what he had meant or done." You can update the language; you can reformulate the phrasing; but do not try to attribute a meaning to an author which bears little plausible resemblance to what they said in their own language.

Rational reconstruction and historical reconstruction can be done together. But often they pull in different directions. The more historicising you do, the more difficult it becomes to engage with an author as a contemporary. Often therefore historical reconstruction can stress how alien or foreign or distant or unfamiliar the past is. It will often be coupled with a sense that historical cultures, languages and philosophy are specific creations or inventions of a context, the language,

\footnotetext{
${ }^{67}$ D Plunkett, "Conceptual history, conceptual ethics, and the aims of inquiry: a framework for thinking about the relevance of the history/genealogy of concepts to normative inquiry" (2016) 3 (2) Ergo 27-64.

${ }^{68}$ Ibid, 52.
} 
geography, economy, science of that time. You might say, on this approach, for example, that the philosophy expressed in ancient Greece is the result of a constellation of unique factors, which we may never be able to recreate or will never reoccur. In a general sense, historical can lead to historicism. An increasing accumulation of artefacts, archelogy, and knowledge of the past can often overwhelm the historian into submission of his or her subject's uniqueness and when juxtaposed with modernity it can generate a sense of strangeness or disconnection with the subject of study.

Additionally, rational reconstruction is often associated with relativism, which would hold there to be no objective truth but only different perspectives on questions of, for example morality, politics or knowledge. It can be linked also to the idea that historical knowledge of the past is in fact inaccessible, isolated in the past and beyond us. That opinion can often lead to a flip of the analysis; now the historian's own views, perspective or prejudices become the focus of study or consideration. Questions may then arise as to how the historian is somehow projecting on to the past, or creating history or construction a narrative and what benefit can therefore emerge from this control of the past. Another aspect of historicism is that often it can be said fragment the present or challenge the present's sense of truth or objectivity. If you stress that past cultures, societies and ideas are contingent or contextually constructed and intricately linked to circumstance, this poses pointed questions to those who would otherwise present their understanding or theory as being independent of contingencies such as language, culture or politics.

However, rather than slip into isolation or completely surrender history to critiques of arbitrary subjectivism, historical reconstruction does try to salvage some knowledge of past. It is an attempt to grasp the ideas or theories of the past. Different methodologies have been developed to bridge the otherwise apparent gap between historicism's alienation of the past and the desire to gather knowledge of those theories and ideas. The most familiar is that of Skinner and the Cambridge School. Skinner developed an approach to the history of thought which built upon Austin's notion of a speech act. Skinner has argued that the history of thought should not be concerned with the motive, meaning or truth of a proposition or idea but only the intention of the speaker or writer. On Skinner's analysis, you can discern the intention of an author from context and language. You get an understanding of an idea through a construction of the linguistic practices of whatever period one is considering. This includes developing an understanding who the statement was made to and the context within which the statement or proposition or idea was uttered.

Historical reconstruction can salvage ideas from the past and emphasis the contingency of today, at least if you follow 
Skinner. Indeed, the Skinner and the Cambridge School more generally are associated with stressing the importance and for some the centrally of language in shaping our ideas and concepts; as language evolves, so do concepts and ideas. Skinner has said that this does not necessarily lead to relativism but what he argues is that it does emphasis the transient nature of the theories, concepts and ideas which we use. It also creates selfconsciousness and inoculates against self-congratulatory histories or theories. Those who write historical reconstructions often challenge, implicitly if not explicitly, the totalising or dogmatic tenancies of 'big ideas' which can be intolerant, divisive and wrong. In other words, historical reconstructions can set a benchmark or pose questions which need to be answered before one can claim to have 'cracked' the 'perpetual' problems of political or moral philosophy. It can also, like rational reconstruction, help generate new ideas. By placing contemporary problems or ideas against the mirror of the past, it can help a writer develop a new way of viewing things, like finding an artefact from the past which inspires a contemporary creation. This is what Skinner did when he spoke of the third conception of liberty, after he explored Hobbes and his context in detail he rediscovered a republican notion of liberty which had been otherwise overlooked or forgotten. ${ }^{69}$ But again, whether it can inspire, challenge or deepen our understanding historical reconstruction is not strictly necessary for theory. This genre cannot say that theory needs to be historical; it can only recommend it and be used to challenge or criticise. It may also reveal possibilities and reset the horizon of what is possible to consider.

It might be worth clarifying what I see as the differences between historical and rational reconstruction. It could be said that both aim to a greater or lesser extent to ascribe to actions of historical actors a degree of intelligibility or rationality; that they both share a concern with understanding either an idea of the past or the formulation of an idea. However, I see two differences. Rational reconstruction will judge or argue with the text in question. Generally, historical reconstruction does not do that. Whereas rational reconstruction is done with the aim of either re-educating, reordering or updating a historical idea, historical reconstruction takes things as they are; it sees, as much as possible, as the past saw things. If the idea was constructed badly, even inconsistently or illogically then so be it. Where things have been said, which are no longer unpalatable historical reconstruction will as much as possible hold its nose and report what was said and intended. For a historical reconstructor there is artificiality in what rational reconstruction does as it goes beyond what either the context or the text would allow. This leads to my secondly difference, which is more important.

${ }^{69}$ Q Skinner, Liberty before Liberalism (1998). 
Rational reconstruction may say something like, "with the help of terminology introduced by Hohfeld and developed by Hart, Grotius' original use right is best described as a liberty or privilege rather than a claim right." 70 It can also assume ideas existed, waiting to be found later; for example, "democratic norms and practice were in a deep sleep for almost two millennia between their ancient birth and modern rebirth." ${ }^{71}$ Or "the New England democratic movement anticipated the Leveller's pioneering application of democratic accountability to representative, constitutional government."72 What rational reconstruction is prepared to do, is attribute a meaning to Grotius's concept of use right or suggest that something was discovered. In both instances, it is assumed, or it appears to be assumed, that the idea existed already or lies in stack waiting for time to run along the shelf and pick it up. I should stress, I do not make criticism here of either approach but I do highlight the difference in approach between historical and rational reconstruction.

\section{Geistesgeschichte}

The last path I want to consider is geistesgeschichte or history of the human spirit, which is in many ways synonymous with Hegel. ${ }^{73}$ In 1822, 1828 and 1830, Hegel (1770-1831) delivered a series of lectures which came to be known as Vorlesungen über die Philosophie der Weltgeschichte (Lectures on the Philosophy of World History). ${ }^{74}$ Hegel argued for a new conception of history and philosophy, a philosophical history or a geistesgechichte. He said "...the Philosophy of History means nothing but the thoughtful consideration of it." "75 Although Hegel was satisfied with this definition, it is somewhat elusive. However, Hegel goes on to explain that, the historian would draw from their sources a story of rational development which could in turn give the events, happens and actions of history a yet unknown meaning and significance. Hegel acknowledged that to "insist upon Thought in this connection with history" may be "unsatisfactory" to some because the historian may assume "Thoughts must be subordinate to what is given" by reality and

\footnotetext{
${ }^{70} \mathrm{~J}$ Salter, "Grotius \& Pufendorf: the right of necessity" in L May \& E McGill (ed), Grotius and Law (2014) 181-200 at 184.

71 J S Maloy, The Colonial American Origins of Modern Democractic Thought (2008) 3.

72 Ibid, 5.

${ }^{73}$ As Collingwood says, "[a]nyone who reads his Philosophy of History by itself cannot but think it a profoundly original and revolutionary work, wherein history for the first time steps out full-grown on the stage of philosophical thought. But when consideration is given to the work of his predecessors [Kant, Herder, Finchte, Schelling], his book becomes far less startling and less original" R Collingwood, The Idea of History (1956) 112.

${ }^{74}$ G W F Hegel, Lectures on the philosophy of history (trans) J Sibree (London, 1914).

75 Ibid, 8-9
} 
facts, which should then shape the type of history one tells. Whereas the philosopher may argue that philosophy "dwells in the region of self-produced ideas, without reference to actuality." 76 To do otherwise - to approach philosophy with this understanding of history and history with philosophy - is to "force [history] into conformity with a tyrannous idea, and to construe it, as the phrase is, 'a priori'. However, Hegel says that the "only Thought which Philosophy brings with it to the contemplation of History, is the simple conception of Reason; that Reason is the Sovereign of the World; that the history of the world, therefore ,presents us with a rational process." 77 On this basis, Hegel says his history of the world will be both of the physical and psychological phenomenon of the world but predominantly of the psychological; or the "Spirit, and the course of its development..."78 In summary, he says the "History of the world is none other than the progress of consciousness of Freedom; a progress whose development according to the necessity of its nature, it is our business to investigate." 79

But the progress of the consciousness of Freedom from the ancient Greeks to the 19th century was not straightforward. The Persians defeated the Greeks; the Visigoths ransacked Rome; the Reformation ended in division; the French revolution descended into tyranny; and so on. "There are many considerable points in History" he says, where "the whole gain of a previous culture appears to have been entirely lost." ${ }^{~}$ However, Hegel sees through this process an important interaction between thesis, antithesis and eventual synthesis; Reason through the actions of men, is working toward the realisation of the Geist. History in of itself - its events, happenings and actions represents for Hegel's philosophical historian the working out of Freedom to an eventual state where there is a full consciousness of Freedom manifest in the world. For Hegel each stage of history represents an idea, which reason, at some point, reveals to be contradictory - for example, Athenians recognised free individuality, which was contradicted by slavery and the unexamined tradition or habits of ancient Greece. The contradiction then leads to the dominant idea which is embodied in a society to an end, and through this process a new form of idea arises. History tracks this dialectic movement, in stages, until eventually it reaches the point of realisation of Freedom.

Hegel's philosophical history is a hard sell to historians. He knew this when he said "the suggestion that history should be philosophical appears to be diametrically opposed to that of the historiographer." ${ }^{81}$ A historian would prefer to say it was his

\footnotetext{
76 Ibid, 9

${ }^{77}$ Ibid, 9

${ }^{78}$ Ibid, 17

${ }^{79}$ Ibid, 20

${ }^{80}$ Ibid, 58

${ }^{81}$ Ibid, 9
} 
or her task to simply "adopt into [history's] records what is and has been actual occurrences and transactions" and to maintain that history "remains true to its character in proportion as it strictly adhere to its data." 82 Many modern historians would say something similar. However, Hegel does not just require a philosophical disposition. Rather to follow a Hegel and his understanding of history, you need to see historical events as being related in a material causal sense but in a teleological and meaningful sense. You see behind the otherwise singular events of history a purpose, the Geist. Or you see the process (dialectics) by which the Geist is continually working towards its realisation. You see history as working towards an end goal. In that sense, you will also understand the individual actions of men and woman as being not just important but also part of a much larger narrative; there is a connection between the actions of individuals, namely the Geist. But men and woman in history do not fully grasp that the work of the Geist, and least not until Hegel. Hence, for Hegel there is an unconscious movement in history which is not explicitly represented or recorded in the reports and accounts we receive from the past. It is through the "cunning of reason" that history steps forward through the actions of men and women. Additionally, for Hegel human actions are done for a reason and are influenced by the ideas we have and a need for self-realisation. Moreover, you will see a process in history which can be used to illuminate the present either by revealing to us the real reason why something happened or by offering to an opportunity to grasp the ultimate purpose of our own life, full consciousness of Freedom.

Hegel is marmite. Schopenhauer said that the brilliance of Kant was squandered by the generation that followed with "the greatest effrontery in serving up sheer nonsense, in scrabbling together senseless and maddening webs of words, such as had previously been heard only in madhouses, finally appeared in Hegel." 83 Despite this, modern philosophers such as Charles Taylor and Alasdair MacIntyre have advocated a Hegelian approach to contemporary philosophical problems. I think MacIntyre and Taylor help us understand what can be taken from Hegel (and what you might leave behind). First, a concern for finding and articulating what Hegel might call the "unreal consciousness" or what Taylor calls, what we have forgotten; second, a form of social theory which stresses that ideas, concepts and theories can operate, influence and shape individuals and society and often these function by providing a limiting paradigm in society; three, a historical awareness which explains the development of ideas and society, arguing that due to inherit contradictions in prevailing paradigms, there is a

\footnotetext{
${ }^{82}$ Ibid, 9

${ }^{83}$ A Schopenhauer, The World as Will and Representation, Vol 1 (1818-19) (trans) E F J Payne (1969) 429.
} 
driving force towards a new paradigm; four, a demand that the historian be in the present as much as the past.

Like Hegel, Taylor and MacIntyre challenge conventional views of what history is. For example, "history" says MacIntyre "in our culture means academic history, and academic history is less than two centuries old." 84 He asks us to consider whether our modern conceptions of what history is, derives from contestable philosophical presuppositions. For MacIntyre, the history of philosophy is not "value-neutral" and his own narrative which divides into stages "presupposes standards of achievement and failure, of order and disorder." 85 History which claims to be value-neutral is on his analysis the product of a mode of thinking (a tradition) which itself had a starting point in the past. According to MacIntyre, once you grasp this, you will then be able to see that what is shaping the practice of history, and how we view the past, are ideas, concepts and practices which are themselves inherited. From this perspective, history becomes the exploration of those ideas, concepts and practices which are inherited, which is an exploration of what people have thought and what has been passed on. Thereafter, MacIntyre suggests there are generally three traditions, all of which have their starting point in the past. But he says through the process of historical philosophy, you are able to determine which tradition is preferable. On those terms, MacIntyre is Hegelian. ${ }^{86}$

Taylor too has argued that "philosophy and history are one." ${ }^{87}$ He says that "it is essential to an adequate understanding of certain problems, questions, issues, that one understands them

\footnotetext{
${ }^{84}$ A MacIntyre, After Virtue, 3rd edn, (2007) 4.

85 Ibid, 3

${ }^{86}$ But he is not in other ways. He argues that if philosophy were to take its history seriously, it would find that modern philosophical disagreements are the result of three rival traditions - Thomist, liberal and post-modern - which are incommensurable. Per MacIntyre, given the incommensurability of these dominate world-views the only hope of progress in philosophy is for the study itself to become historical. In becoming historical, you discover that only one of these rival theories can explain why these other traditions emerged and why only one of these traditions can be an improvement upon these other traditions. For him, the encyclopaedic (or liberal tradition) and the genealogical tradition (or post-modern) traditions do not have the capability within their own systems or internalised rationalities to explain and incorporate their rivals, it is only the Thomist tradition which has the capabilities and resources to speak to its rivals and to demonstrate where each went wrong and why it is an improvement. History for MacIntyre offers a backdrop against which you can arbitrate between rival theories. And in his own history of rationality and morality, MacIntyre tells a story of a rise and fall of the Thomist tradition which was cast aside by the Enlightenment. See A MacIntyre, Three Rival Versions of Moral Enquiry: Encyclopaedia, Genealogy, and Tradition (1990).

${ }^{87}$ C Taylor, "Philosophy and its past" in R Rorty, J B Schneewind, Q Skinner (eds), Philosophy in History: Essays in the Historiography of Philosophy (1984) 17.
} 
genetically." 88 But Taylor says that we are in part hamstrung because the "discourse [of history or anthropology] we use is continuous with that of our forebears. We write books and treatise like [James George] Frazer, with claims supported by not totally dissimilar canons of evidence and argument." 89 Even though we may have "big doubts" about "some of the 'scientific' claims $" 90$ we make about the past and our ability to truly perceive and understand the past in an "objective manner" we continue to cast history or anthropology or historical studies in that light. However, Taylor "rejects altogether the Hegelian single line of development" but argues for retaining "something like the notion of potentiality." 91 By potentiality, Taylor means "we have it in us [whether Greek or modern] from the beginning to become what we later become." $92 \mathrm{He}$ clarifies however that to "speak of potentialities does not mean to suppose a unitary set. We can and increasingly do recognize diverse lines of possible development, some of which seem incompatible with each other, at least at first blush." 93 However, Taylor does argue that history "seems to exhibit some irreversible developments." "94 For Taylor, there is something stable through history which is the potential of man to achieve what he later achieves.

Taylor also explains the relationship between history and philosophy and how each can work together to articulate, reveal or rediscover implicit paradigms or forgotten assumptions (what Hegel might have called a false consciousness). First, Taylor says philosophy is "an activity which essentially involves among other things, the redescription of what we are doing, thinking, believing and assuming in such a way that we bring our reason to light more perspicuously or else make the alternative more apparent, or in some way or other are better enabled to justified stand to our action, thought, belief, assumption." 95 However, secondly, Taylor does not think that it is optional to be historical; to attempt a redescription, without recourse to history is to miss the point and importantly to assume too much. Rather he stresses that there has often been a "forgetting" or a backdrop which needs to be rediscovered, articulated and illuminated before we are able to offer an adequate redescription of what we are doing, thinking or believing in the present. History does this. Hence, he says the reason a "genetic account" or historical of our understanding is "indispensable has something to do with the

\footnotetext{
${ }^{88}$ Ibid, 17.

${ }^{89}$ C Taylor, "History, Hegel and Comparison" in F E Reynolds \& David Tracy (eds), Myth and Philosophy (1990) 39.

${ }^{90}$ Ibid, 38.

${ }^{91}$ Ibid, 54.

92 Ibid, 51.

${ }^{93}$ Ibid, 53.

94 Ibid, 52

${ }^{95}$ Ibid, 18.
} 
nature of the forgetting" of the present. ${ }^{96} \mathrm{He}$ goes on to say that "if you want to break loose, you need to understand the past in order to liberate yourself." 97 It is by going backwards and uncovering or discovering the debates, decisions and arguments which have constructed or animated our received paradigms or boundaries that we can then make progress. He says "an outlook which may have been won by a heroic effort to be the basis of widespread social practice" may continue "to inform the life of a society" but at the same time assumes such a status that it becomes "virtually unchallengeable to common-sense even though the original formulations and especially their background reasons may be widely neglected, rehearsed only by specialists." ${ }^{98}$ For example a great deal of contemporary contract theory writes against the background of political theory and historical narratives. This is unsurprising if you take the seventeenth century as setting the paradigms of contemporary political and legal theory. Grotius, Hobbes, Pufendorf, Locke, inter alia, wrote against a backdrop of purposively excluding theology, of appealing to abstract or practical reason, and using hypothetical states of nature to describe the origins of the state, rights and law.

Modern Hegelians also stress that philosophical history should focus as much on the past as on the present. Both MacIntyre and Taylor stress that a philosophical history should try to inform, reveal and explain the present; that is, how the past effects or has constructed the present, and how our thinking and understanding of the world has an origin in the past. This approach, gives a historian a firm footing and purpose. It also avoids the arid fields of antiquarism or the speculative planes of predicting the future. Again, you do not need to say that all history, should be concerned with explaining or describing the "whys" and "hows" of the present but if you follow a Hegelian approach then you will invariably be involved with such a task to a great or lessor extent. You may see you task as to reveal the false consciousness of the present or merely to shed light upon what we have inherited from the past.

Rorty says that the geistesgechichte is uncharacteristically sure about what philosophy is whereas other philosophers are not so sure. More generally, Rorty questions whether the Hegelian approach has not presupposed a great deal - the purpose of philosophy, the problems it deals with and the way these problems should be solved. In part, Rorty's concern is that a modern Hegelian may take a conception of what philosophy is and drive into the past with a self-assured (modern) conception which excludes as much as it includes specific

\footnotetext{
${ }^{96}$ C Taylor, "Philosophy and its past" in R Rorty, J B Schneewind, Q Skinner (eds), Philosophy in History: Essays in the Historiography of Philosophy (1984).

${ }^{97}$ R Rorty, "The Historiography of Philosophy: Four Genres".

${ }^{98}$ Ibid.
} 
writers, texts and ideas. He says that often such histories include writers or texts which are unusual or not normally considered to be speaking to or address the same problems or questions. Rorty notes that this type of philosophical history stays at the level of problematics and is less concerned with solutions. His implication is clear, Hegelian histories are unconstructive and do not offer anything substantive other than critique and an explanation of problems. He says that the Hegelian historian asks "why should anyone have made the question of __ central to his thought?"99 The modern Hegelian asks this with the purpose of establishing an ongoing problem which they believe only history can make evident to philosophy. Or you might say that they are trying to explain modern problematics by returning to the past, although Rorty's suggestion is that Hegelians manufacture the very problems which then serve as the subject of analysis.

He goes on to say often philosophical histories "want to justify the historian and his friends in having the sort of philosophical concerns they have - in taking philosophy to be what they take it to be - rather than in give in the particular solution to philosophical problems they give. It wants to give plausibility to certain image of philosophy rather than to give plausibility to a particular solution of a given philosophical problem." 100 Rorty suggests that philosophical historians may unfairly disagree with a philosopher from the past because he hasn't written about or considered or adequately addressed a question which he negligently, wrongfully, unconsciously or unscrupulously forgetful or neglectful of. "He does this by assembling a cast of historical characters and a dramatic narrative that show how we have come to ask the questions we now think inescapable and profound." ${ }^{101}$ Here Rorty is gesturing to the excavation of the "false consciousness" of society and what that entails. Often it can involve the creation of a history which is not necessarily recognisable to or deviates substantially from existing histories. More generally, as Hilary Putnam observed in supposing hidden patterns and powers which operate in history, Hegelians may see a relationship between, for example, Descartes, Adam Smith and James Bond - i.e. individualism - whereas to a non-Hegelian there is nothing much at all connecting these characters. ${ }^{102}$ To be a Hegelian you often must see what is otherwise not evident - God, historical materialism, the spirit of the age, etc. - which is difficult for a sceptic, materialist, nominalist or pragmatist.

Nevertheless, despite Rorty demonstrating the characteristics, patterns and strategies of a Hegelian approach, he is nevertheless sanguine about its continuation; he is positive

\footnotetext{
${ }^{99}$ Ibid.

100 Ibid.

101 Ibid.

${ }^{102}$ H Putnam, "Liberation Philosophy", LRB, 8 (5) (1986) 3-5.
} 
about its contribution. He does not think that we can do away with the historiography of philosophy; he does not think that "thick intellectual history...wary of canons (philosophical, literary, scientific, or other)" are enough. ${ }^{103} \mathrm{He}$ argues that we need to keep Hegelian approaches because: ${ }^{104}$

"...we cannot get along without heroes. We need mountain peaks to look up toward. We need to tell ourselves detailed stories about the mighty dead in order to make our hopes of surpassing them concrete. We also need the idea that there is such a thing as "philosophy" in the honorific sense - the idea that there are, had we but the wit to pose them, certain questions that everybody should always have been asking. We cannot give us this idea without giving up the notion that the intellectuals of the previous epochs of European history form a community, a community of which it is good to be a member. If we are to persist in this image of ourselves, then we have to have both imaginary conversations with the dead and the conviction that we have seen further than they. That means that we need Geistesgeschichte, self-justificatory conversations."

Because Rorty has a generous (undefined) conception of what philosophy is, he is happy for there to be all three genres of rational reconstruction, historical reconstruction and geistesgeschichte to co-exist. The task of philosophy is, for him, akin to literature or poetry or an artistic expression of human experience.

\section{Conclusion}

In summary, today you may hear complaints about private law theory's approach to history. In the 1970s and 1980s, however, there was a great deal of historical writing relating to (but not always exclusively) about private law. ${ }^{105}$ Nevertheless, in recent years history has figured less in private law theory or those engaged in history and theory have neglected the theoretical side of their work for history. ${ }^{106}$ In this paper I have tried to suggest, if the theorist were to address these complaints how they might do their theory and draw upon the methodological approaches taken in philosophy, particularly Anglo-American analytical

\footnotetext{
${ }^{103}$ Rorty, "Four Genres" 272.

${ }^{104}$ Ibid, 272-273.

105 For example, L M Friedman, A History of American Law (1973); B Gilmore, Death of Contract (1974); M Horwitz, The Transformation of American Law, 1870-1960 (1977) P Atiyah, The Rise and Fall of the Freedom of Contract (1979); J Gordley, The Philosophical Origins of Modern Contract Dotrince (1991)

106 Of course there are exceptions, the work of James Gordley is the most prominent example.
} 
philosophy. Of course, every theory of law in some way implicitly or explicitly deals with the past and has some sort of conception of history or time. It may be undeveloped, rudimentary or deliberately side-lined but what has gone before is part of the fabric of law, legal reasoning and how we analyse; it just might not always be evident or examined. But I have tried to show in this paper three possible ways through which you can theorise about private law. It may be that, for example, critical legal histories share the most in common with a contextualised approach whereas others may be more inclined, whether knowingly or not, towards a Hegelian approach. But there are other approaches and ways in which history and theory can be used together. Therefore, I understand these three approaches outlined above as strands of theoretical writing which have a historical sensibility or which overtly include and incorporate the past (or history) into their theorising. I do not see these as definitive categories, there could be more; this division is far from absolute and each may in some ways overlap with the other but if we are going to do private law theory historically, these are potential paths. 